\title{
THE SOCIALISTS \\ AND THE WORKERS OF PARIS: THE AMICALES SOCIALISTES, 1936-40*
}

The Popular Front's victory in the legislative elections of April-May 1936 caused a great sense of relief and then a joyful upsurge of hope and idealism in its supporters. Spontaneously, thousands of workers began to occupy shops and factories. On June 4, when the Blum government came to office, the strikes had begun to paralyze the economy. In the next two weeks, perhaps because it was clear that the Blum government was not going to suppress the strikes but rather to negotiate an end to them, perhaps because by that time it was also clear that neither the Confédération Générale du Travail nor the Communist and Socialist parties would try to take advantage of the situation for an insurrectionary purpose, the strikes spread like wildfire throughout the country. Hundreds of thousands of workers apparently wanted to guarantee, through "direct action", that the benefits of the Matignon accords and of the promised legislation would apply in their industry or region. ${ }^{1}$ It was in these conditions that the Blum government managed to get the conservative Senate's approval for the most progressive social reforms of the Third Republic.

During the summer and fall of 1936, while the Blum government wrestled with intractable economic problems, hostile financial circles, conservative Senators, and the difficulties arising out of the Spanish Civil War,

\footnotetext{
* The author is grateful to the Canada Council for a grant which facilitated the preparation of this article.

1 The strikes have inspired an interesting historiography. See in particular Antoine Prost, "Les Grèves de Juin 1936", and the ensuing discussion, in: Léon Blum, Chef de Gouvernement 1936-1937 (Paris, 1967), pp. 69-107; Georges Lefranc, "Problématique des Grèves françaises de mai-juin 1936", in Essais sur les problèmes socialistes et syndicaux (Paris, 1970), pp. 127-40; id., Le Mouvement Syndical sous la Troisième République (Paris, 1967), pp. 335-47. The "spontaneous" thesis supported by Prost and Lefranc is opposed, at least for the coal mines of the Nord and Pas-de-Calais, by Raymond Hainsworth, "Les Grèves du Front populaire de mai et juin 1936: Une nouvelle analyse fondée sur l'étude de ces grèves dans le bassin houiller du Nord et du Pas-de-Calais", in: Le Mouvement Social, No 96 (1976), pp. 3-30.
} 
many of its supporters chafed at the slowness with which the new legislation was translated into reality in their shops and factories. ${ }^{2}$ As the Blum government, hampered by internal disagreements, began to display increasing pusillanimity - adopting a policy of "non-intervention" in the Spanish Civil War, devaluing the franc in October 1936 despite its declared intentions, presiding over a rapid rise in the cost of living which eroded the 12-13 percent wage increases negotiated in June, and finally announcing a "pause" in further reforms in February 1937 in order to foster the confidence of the business community -, discontent grew markedly in the working class and within the SFIO itself. Advocates of returning to "the methods of June" multiplied. ${ }^{3}$ But the greatest beneficiaries of the Popular Front experience, both in the optimistic early phase and in the later depressing phase, were the Communists. They had received most of the credit for having initiated the Popular Front alliance in the first place, and their new support for a hardy national-defence strategy, standing in marked contrast to the confused positions of the SFIO, added to their appeal. Refusing to participate in the Blum government but providing votes for it in Parliament, the Communists were in the happy position from June 1936 forward of being able to claim credit for the government's successes while blaming its failures on the Socialists and Radicals. To the discomfiture of their partners, the Communists organized campaigns for the immediate introduction of the forty-hour week in all industries, protests against the high cost of living and devaluation, and demonstrations for direct aid to the Spanish Republicans. ${ }^{4}$

Communist successes in attracting supporters in 1935-36 naturally caused great concern in the Socialist Party. The Socialists' concern was less about the PCF's recruitment of new members, however, than about the danger that the Communists might be able to take over the CGT. After

${ }^{2}$ On employer resistance to the reforms achieved in June and July 1936, see René Rémond and Janine Bourdin, "Les Forces adverses", in: Léon Blum, op. cit., pp. 137-59, and the discussion and documents, pp. 160-204; and Jean-Noël Jeanneney, François Wendel en République: L'Argent et le pouvoir, 1914-1940 (Paris, 1976), pp. 560-74.

3 On working-class discontent, see Arthur Mitzman, "The French Working Class and the Blum Government", in: International Review of Social History, IX (1964), pp. 363-90. On the rise of the left-wing opposition within the SFIO, see Donald N. Baker, "The Politics of Socialist Protest in France: The Left Wing of the Socialist Party, 1921-39", in: Journal of Modern History, XLIII (1971), pp. 2-41, and Jean-Paul Joubert, Révolutionnaires de la S.F.I.O.: Marceau Pivert et le pivertisme (Paris, 1977). La Révolution Prolétarienne provided regular accounts of the discontent in the factories of the Paris region in 1936-37.

${ }^{4}$ Daniel T. Brower, The New Jacobins: The French Communist Party and the Popular Front (Ithaca, N.Y., 1969), chs 5-6. 
fifteen years of separate existence, the non-Communist CGT and the Communist Confédération Générale du Travail Unitaire had merged, in a congress held in Toulouse in March 1936, to form a "unified" CGT. The confédérés headed by Léon Jouhaux had agreed to the merger in 1935 because of a calculation that their greater numbers would enable them to swallow and digest the Communist unitaires. The latter, inspired by the imperatives of the Popular Front tactic, apparently calculated that they would at least maintain their share of the membership while deriving for the PCF whatever benefits could be gained from a unified labour movement. The Popular Front's victory in 1936, accompanied by the wholesale radicalization and politicization of workers, created dramatically new conditions which destroyed the bases of the confédérés' calculations. The total membership rose from around 1,000,000 for both unions in December 1935 to around 4,000,000 in the "unified" CGT a year later. ${ }^{5}$ Many of the new recruits threw their support to the Communist wing of the CGT, with the result that the Communists were soon able to establish control over new sectors of the labour movement, especially in the Paris region. ${ }^{6}$ Communist expansion, which the non-Communists tended to blame on deliberate "colonization" rather than on the dispositions of the new recruits, inspired an organized anti-Communist faction known as Syndicats after its weekly organ. ${ }^{7}$ Thereafter the internal life of the CGT was characterized by con-

5 Antoine Prost estimates that the CGT never attained more than 3.8 million members in the Popular Front period, while Georges Lefranc accepts the figure of around 5 million emanating from the CGT itself. Prost, La C.G.T. à l'époque du Front Populaire 1934-1939: Essai de description numérique (Paris, 1964), p. 42; Lefranc, Le Mouvement Syndical, op. cit., pp. 347-51, 415-16.

6 By the end of 1936 the Communists had taken control of the national federations of railroad, construction, textile and metallurgical workers, several "unions départementales" previously dominated by the ex-confédérés (e.g., in the Somme), and some occupational branches (e.g., the hotel, café and restaurant workers organization). When the CGT and CGTU had merged, they had established an Union des Syndicats for the Paris region, with fifteen representatives for each side on the executive committee; a year later the balance of forces was such that the Communists could claim twenty-three seats to only seven for the ex-confédérés. See Georges Dumoulin, "Colonisation syndicale", in: Syndicats, 22 January 1937; Decques, "Va-t-on continuer à compromettre l'unité morale des syndicats?", ibid., 7 January, for details on the Somme and Seine areas; "Le Congrès de l'Union des Syndicats de la Région Parisienne", in: La Révolution Prolétarienne, No 240 (10 February), pp. 463-64; and the comment by Maurice Chambelland, "Renaissance du Syndicalisme", ibid., p. 461.

7 On the growth of the organ, see Marie-France Rogliano, "L'Anticommunisme dans la C.G.T.: 'Syndicats"', in: Le Mouvement Social, No 87 (1974), pp. 63-84. Communist "colonization" of the CGT was a major theme of the faction. However, some of its leaders occasionally admitted either that many of the new recruits were more "political" in orientation than syndicalist (Raymond Froideval in Syndicats, 29 April 1937) or that the 
stant tussles between the Communist and non-Communist elements, with the latter divided, in turn, into several more tendencies by the growing international crisis.

It was in this general context of working-class instability, of growing Communist influence in the working class, of the fragmentation of the non-Communist elements within the CGT, and of mounting disillusion with the Popular Front and with parliamentary activity that the Socialists finally decided to experiment with new approaches to organizing a mass following. The chief vehicle with which they experimented was a front organization known as the Amicales Socialistes d'Entreprise. By contrast with Socialist Party sections, which were based on place of residence, the sections of the Amicales Socialistes were based on the place of work shops, factories, stores. Each section was to be led by SFIO militants, but its aim was to attract as many sympathizers as possible to causes supportive of Socialist Party policy. The creation of the Amicales Socialistes marked a break with long-standing Socialist policy, in respect to both the forming of front organizations and organizing at the place of work. The Amicales Socialistes came into existence, moreover, at a time when Socialists were increasingly divided over whether the party's aim should be to stabilize or to revolutionize the working class. Thus, their development was to be intertwined with the party's internal struggles of the period. Their story reveals a good deal about the stresses and strains at work in French Social Democracy in that period.

Before looking at the specific origins of the Amicales Socialistes, we must consider one other element in the background: the discussion within the SFIO about the relationship between the party and the masses in the spring of 1936. The debate over the proper nature of that relationship, given the circumstances of the time, helps to explain why the initiative for the Amicales Socialistes came from within the party hierarchy and what the several factions thought the new organization could or did represent.

Communists' primary form of organization - the cellule d'entreprise - simply meant that the Communist unionists were more homogeneous and coherent in outlook than their non-Communist rivals (René Belin, "Les Syndicats et les partis", ibid., 2 September). Both Prost and Lefranc put far more weight on factors other than "colonization" in their discussions of growing Communist influence within the CGT - although efforts at colonization were made from time to time. Prost, La C.G.T., op. cit., pp. 152-53; Lefranc, Le Mouvement Syndical, pp. 377-78. 
The Socialists and the Problem of the Masses, 1936

Our concern here is not with the full range of Socialist views on the historical role, real, imagined, or potential, of the "masses". Rather, it is with the specific form in which the Socialists envisaged that problem in May 1936, just as the strikes were beginning and just prior to their party's entry into office. As Socialists saw things then, the problem confronting them was not that of the relationship between their party and the "masses" in some general sense, but rather that between their party and what was commonly described as the "mouvement de masses" embodied in the Popular Front.

Most Socialist commentators had begun to realize, in the fall of 1935 , that for many of its supporters the Popular Front had become more than an electoral combination to bar the door against "fascists" and to give France a "New Deal" economically. For many supporters, the Popular Front was becoming something of a crusade - one which they interpreted variously, according to their interests and ideologies, but in which the very idea of unity played a key psychological role. The pledge of the Popular Front taken by party leaders on July 14, 1935 - became a kind of talisman of unity, so often was it to be invoked in the next year. The French Left had so long squandered its strength in squabbles that, for many militants and sympathizers of the Communist, Socialist and Radical parties, the notion of "unity" had taken on almost magical proportions. ${ }^{8}$ Moreover, as the German example had shown, the lack of Leftist unity could have extremely grave consequences. The hysterical propaganda of a part of the Right during the 1936 election campaign - "Better Hitler than Blum!" underlined that point and confirmed for many the absolute necessity for Leftist unity. When the elections produced victory for the Popular Front, the spirit of unity grew even stronger. If the strikes of May-June had a festival atmosphere, it was because they were a feast of unity, of solidarity, as much as a feast of relief, of new-found self-confidence and power. To most contemporaties, the strikes did not mark a break from the Popular Front "movement" they had witnessed growing during the previous year; they seemed a continuation, further concrete proof of the existence of the "movement" and of the power to be found in solidarity.

8 In an effort to explain this phenomenon, John T. Marcus, French Socialism in the Crisis Years, 1933-1936: Fascism and the French Left (New York, 1958), pp. 181-85, attempted to describe the sense of unity in terms of an antifascist "mystique". For a more recent discussion of the hold of the idea of unity on the Communists and Socialists, see Jean-François Gelly, "Recherches sur les problèmes de l'unité organique du P.C. et de la S.F.I.O. à travers les sources diverses sur les deux partis, du pacte du 27 juillet 1934 à la fin de l'année 1937" (Mémoire de Maîtrise, Histoire, Paris I, 1974), pp. 17-25. 
In trying to fix their position on the question of how the SFIO should relate to the mass-movement dimension of the Popular Front, the Socialists naturally took diverse positions, as they did on most questions. Discussions of the problem occurred at several levels and changed focus as events unfolded. All parts of the Socialist spectrum were concerned from the start about the possible confusion, in the minds of workers, between the goals of the SFIO and the more limited ones of the Popular Front. From all sides there was a chorus of demands for "specifically Socialist propaganda" and for improved propaganda techniques - evidence of a deep concern that the party was being by-passed by events. ${ }^{9}$ From an early point, too, everyone agreed that the party's regulations governing individual memberships in other political formations and contacts between Socialist sections and federations with units of other parties were of central importance; and indeed these regulations were to become the specific focal point on which the debate over the party's relationship to the masses was to turn. In 1926, to counter the Communists' "unity from below" tactic, the party had laid down strict rules forbidding membership in other political organizations, forbidding participation in meetings organized by other groups, and forbidding all party-to-party contacts not expressly approved by the Commission Administrative Permanente (CAP) or a national-council meeting. ${ }^{10}$ These rules had been broken by the Seine federation in February 1934, an act approved retrospectively; ${ }^{11}$ but they had been enforced in all other cases, notably against a handful of Trotskyites and other gauchistes in the fall of 1935. The Popular Front was to raise more plaguesome problems because it involved a potentially far greater number of disciplinary cases.

From the start of the Popular Front the SFIO's leadership had insisted that all Popular Front committees would consist of delegates of all of the organizations that signed the Popular Front pact at the national level. The Socialists were wary of Communists, Trotskyites, and others who had tried for years to fragment their party by appealing for "unity at the base" or to

${ }^{9}$ For example, see Robert Dupont, "Propagande spécifiquement socialiste", in: La Bataille Socialiste, No 92 (January 1936); Emile Farinet, "Réflexions sur la propagande", in: Le Populaire, 9 December 1935; and E. Gaillard, "Service de propagande", ibid., 26 May 1936.

10 The rule was originally formulated to control Maurice Maurin's faction, known as Action Socialiste, which was advocating fraternization with the Communists. See the resolution of the Clermont-Ferrand congress, 1926, in Parti Socialiste, XXIVe Congrès National, Rapports, 1927, pp. 8-9. The rule was next applied in a dramatic way against Socialists who joined the Amsterdam-Pleyel movement.

11 Marceau Pivert, addressing the 1936 national congress. Parti Socialiste, XXXIIIe Congrès National, Compte rendu sténographique, 1936, pp. 155-56. 
divert its energies by consuming militants' times in non-party activities. However, given the nature of the developing popular movement, the restriction on participation in various informal committees became difficult to uphold. By comparison with the Communists and the Radicals, the Socialists appeared inflexible and party-bound at a time when transcendental unity was called for. Before the legislative elections of April-May 1936, the problem was somewhat mitigated by the electoral focus of all activities and by the presence of Socialist candidates in all areas to provide local direction. Once the elections were over and the strikes had begun, the disciplinary problem became unmanageable. Many Socialist militants simply ignored their party's rules and joined the strike and "unity" committees that sprang up everywhere, notably at the place of work.

The arguments over what to do in this new situation crystallized in the debate leading up to and consummated at the extraordinary national congress of May 30 to June 1. The party's bureaucrats wanted to reaffirm the party's regulations. Paul Faure's policy resolution for the congress expressed the view of what Louis Lagorgette called "la vieille gauche" of the party on the issue. It warned militants about "the inconveniences and dangers" of individual memberships in "all sorts of leagues and associations", including Popular Front committees, and in effect recommended sustaining the existing policy. Lagorgette, chairman of the Comité National Mixte of the Jeunesses Socialistes, supported this defensive position with great passion, no doubt because he had been at the centre of bitter disputes within the youth organization over just that issue. ${ }^{12}$ The contrary view was upheld notably by the two major factions of the left wing, Bataille Socialiste and Gauche Révolutionnaire, and by several individuals who thought that the old policy would permit the party to be by-passed by events.

Of the two left-wing factions, Gauche Révolutionnaire wanted the more drastic revision in the party's rules. Founded in the autumn of 1935, when the mystique of the Popular Front was growing rapidly, consisting of a small group of Trotskisant and Spartakisant intellectuals and activists led by Marceau Pivert, Gauche Révolutionnaire was profoundly ambivalent about the Popular Front. Its members could see that the Popular Front was

12 See Fred Zeller, Trois points, c'est tout (Paris, 1976), pp. 56-91; Jean Rabaut, Tout est possible! Les "Gauchistes" français 1929-1944 (Paris, 1974), pp. 166-203; Daniel Guérin, Front populaire, révolution manquée: Témoignage militant, 2nd ed. (Paris, 1970), pp. 92-98; Maurice Jacquier, Simple Militant (Paris, 1974), pp. 91-94; Yvan Craipeau, Le Mouvement trotskyste en France (Paris, 1971), pp. 119-51; Jenny Praeger, "La Fédération de la Seine de la Jeunesse Socialiste, entre 1934 et 1939" (Mémoire de Maîtrise, Histoire, Paris I, 1972), pp. 15-49. 
a combination of organizations collaborating for limited purposes, and that neither the Radical nor the Communist party was as eager for social and economic transformation as left-wing Socialists were. But they did not want the Popular Front to remain only what the parties would permit it to be. Believing in the creativity of the masses and the self-interested limitations of political parties, they feared that the Popular Front might hinder the growth of a large-scale mass movement. Accordingly, they appealed to all revolutionary elements to join hands in a Front Populaire de Combat which would serve as a congealing and radicalizing force within the Popular Front alliance, one that would encourage the mass-movement dimension. The Pivertists were not especially concerned about the formal fusion of these revolutionary elements in a new organization. Unity would spring from unity of action. They were content to co-ordinate their activities with other revolutionaries and to foster like-minded, if independent, groups outside the SFIO. Just as the Popular Front was an alliance of independent organizations, so the Front Populaire de Combat would coordinate rather than fuse or transcend its constituent elements. ${ }^{13}$

In the Pivertist view, a revolutionary party should serve as a catalyst for mass action - a catalyst which raises consciousness by education and example, which inspires and canalizes mass action but which does not try to restrict it to narrow channels. Although unhappy with the SFIO, the Pivertists could see no practical alternative to it in the 1930's, for it was open, democratic, persuadable, and large. They tried to convert the party's members to their point of view. But at times their point of view was rather cloudy, notably in 1936. Although Pivert became famous for publishing an article entitled Tout est possible, ${ }^{14}$ a close reading of his speeches and articles during that period indicates that he was thinking of action which would support the Blum government, not of revolutionary action outside the legal channels. He seemed to fear conservative backlash, resort to violence, more than to hope for a bloody breakthrough to a new dispensation. He told the special congress:

Ces Comités de masses, ne doivent pas être utilisés comme cela est peut-être possible, pour essayer de créer des soucis au gouvernement. Mais plutôt en vue de tâches concrètes spécifiques. Par exemple, création des organismes d'auto-défense, des jeunes gardes socialistes, de la garde populaire antifasciste. ${ }^{15}$

13 "Motion pour le Congrès National", in: La Gauche Révolutionnaire, No 8 (10 May 1936).

14 Le Populaire, 27 May 1936; reprinted in Jean-Pierre Rioux, Révolutionnaires du Front populaire: Choix de documents, 1935-1938 (Paris, 1973), pp. 154-58.

15 Compte rendu, op. cit., p. 167. 
In May 1936, Pivert's chief demands on the SFIO were that it sponsor the creation of a multi-party Garde Populaire Antifasciste and that it permit its members to participate in the "popular" committees arising on all sides.

Bataille Socialiste's argument in favour of a change in policy was rather different. Its leader, Jean Zyromski, saw the Popular Front in a world context. For him, the Popular Front was above all an antifascist political combination designed to keep France out of the hands of the fascists and to maximize French military strength in the face of Hitlerian Germany; its reformist potential was limited and secondary, talk of its immediate revolutionary potential a dangerous delusion. This view did not prevent Zyromski from seeing the huge "popular" dimension of the Popular Front tactic. Indeed, for him the mass movement was proof of the realism of the tactic, and he concluded that the party should encourage the spread of the movement whenever and wherever it could, without waiting for formal inter-party agreements to be worked out. As he told the national congress, the "masses" had not always been behind the Socialist or Communist parties or the trade unions, and the occasion should not be lost to enter into direct relations with the mass movement. He warned that sticking with the old rule of prohibiting membership in other organizations would be ignored by militants, making a mockery out of the party's rules. The party would have to find new ways to stay in touch with the mass movement that was developing: "il faut chercher les solutions d'accord qui garantiront l'armature organique du Parti et qui permettront au Parti, le maximum de rayonnement, le maximum d'influence et le maximum de pénétration dans tous les milieux antifascistes." Zyromski concluded with an appeal for party unity in order to permit the Blum government to enter office with united party support and with an appeal for redoubled efforts in the search for unity with the Communists. ${ }^{16}$

Supporting the left wing's appeals for a change in policy were several articulate individuals who did not clearly belong to any faction. Of them, André Philip was the most eloquent. ${ }^{17}$ The issue proved so divisive that the congress decided to close the public discussion and place the matter in the hands of the committee, where it was argued for seven hours. In the end, Zyromski's middle-ground position was adopted "unanimously". These were the key phrases:

Le Parti est certain que tous ses membres sauront trouver les moyens d'éviter les inconvénients et les dangers que peuvent présenter leurs ad-

16 Ibid., pp. 137-38.

17 Ibid., pp. 128-32. In the skirmishing for seats on the CAP Philip was originally left off of the new roster; but when the news reached the floor of the congress the left wing, grateful for Philip's support, quickly offered him a seat from its allotment. 
hésions aux divers groupements antifascistes qui risquent de diminuer ce qu'ils peuvent donner d'activité à leur Parti.

Ils se rappelleront que les Comités locaux ou régionaux de Front populaire ne peuvent, d'après son règlement même, être constitués qu'à l'image du Comité national par les seuls délégués des organisations adhérentes au Front populaire, sans cotisation et toute décision d'action devant être prise à l'ùnanimité. ${ }^{18}$

Despite the apparently stern wording of this change in policy, it nonetheless pleased even the representatives of Gauche Révolutionnaire, for they were now given a free hand to "create Popular Front committees everywhere". 19

The discussion of the mass movement growing around the Popular Front and of how the SFIO should respond in May 1936 indicates that the major change in party policy that eventually came about - the Amicales Socialistes - was not envisaged at that time. It is also clear that as of May and June 1936, at the height of the sit-in strikes, neither of the left-wing factions in the SFIO was thinking of a distinctive Socialist front movement at the place of work. The initiative appears to have come from other quarters, and somewhat later, although the beginnings can be traced back to the time of the congress.

\section{The Amicales Socialistes d'Entreprise}

Just a few days before the national congress was held, Le Populaire printed a small announcement of a "private meeting" to be held on May 25 by officials of the Seine federation. There is no report in Le Populaire or elsewhere on what took place at that meeting, but its significance can be derived from the announcement itself, which was drafted by Robert Dupont, propaganda secretary of the Seine federation. The announcement read, in part:

La propagande spécifiquement socialiste devra être renforcée. Les sections auront à coeur de travailler à la formation socialiste de nouveaux adhérents qui, chaque jour, prennent le chemin de notre organisation.

D'autre part, le travail en commun avec les autres organisations de la classe ouvrière, l'action des comités locaux de coordination et des comités de Front populaire devront être poursuivis sans relâche tant que notre but suprême ne sera pas atteint: la réunification des forces ouvrières sur le terrain politique.

18 Ibid., p. 254. The only published account of the discussions within the resolutions committee was that of René Modiano, in "Ç'aurait pu être un beau congrès!", in: La Gauche Révolutionnaire, No 9 (15 June 1936).

19 Pivert, "Faisons le point", ibid. 
Pour entretenir nos camarades responsables des projets fédéraux d'action et de propagande et de coordination, le bureau fédéral organise, ainsi que nous l'avons annoncé hier, une nouvelle réunion privée d'information qui aura lieu [. . .] le 25 mai. [. . .]

Y sont convoqués tous les membres des bureaux de section, les militants et propagandistes fédéraux et les secrétaires des comités de presse. ${ }^{20}$

Shortly after that point Le Populaire began to publish a regular request for the names and addresses of militants in the Paris region who had been designated as "camarades prenant part à la propagande populaire". By August, the "camarades" appear to have become known as agents de coordination, ${ }^{21}$ a change which may suggest that the creation of committees had given way to co-ordination of already existing groups. By August, the wind had gone out of the sails of the SFIO and it was beginning to experience the roiling waters of discontent with the Blum government. Increasingly Socialist organizers found themselves on the defensive. The shift in title was probably an indication of the change.

The birth of the Amicales Socialistes belongs to the defensive phase of the Socialists' Popular Front experience. They grew out of the activities of the co-ordination agents. The idea to create the Amicales Socialistes came from Francis Desphelippon, secretary of the agents de coordination in the Seine. Here is how the idea was first mentioned in Le Populaire, on August 26:

La Fédération socialiste de la Seine a organisé dernièrement, sous la présidence de [Claude] Just, une séance d'information sur l'utilité et le rôle des agents de coordination. [...]

Desphelippon, dans un brillant exposé, montre comment la propagande doit être réalisée dans l'usine. Les sections de quartier devant travailler elles aussi à faciliter les relations entre les agents d'usine et tous ses membres. Il appelle en outre à tous les secrétaires de section l'urgence de désigner un agent de coordination qui devra prendre contact le plus tôt possible, avec lui ou avec [G.] Prieur à la Fédération.

Le conférencier invita les agents de coordination présents à cette séance de commencer sans retard leur travail. ${ }^{22}$

On September 9 all of the agents de coordination in the Seine attended a meeting where the idea was spelled out further. On September 18, the initiative was taken to the rank and file, which was invited to participate in

20 Robert Dupont, "Dans la Seine”, in: Le Populaire, 22 May 1936 (La Propagande Socialiste section).

21 "A la Fédération Socialiste de la Seine", ibid., 26 August, and "Agents de Coordination de la Seine", ibid., 8 September.

22 "A la Fédération Socialiste de la Seine", loc. cit. 
"the constitution of amicales and liaison groups at the place of work". ${ }^{23}$ The meetings that resulted from this new policy were announced regularly on the last page of Le Populaire under the rubric "Travailleurs socialistes, prenez note". One dimension of Desphelippon's thought that had not been mentioned earlier immediately became clear: the Amicales Socialistes were to consist not only of party members but also of "sympathisants". ${ }^{24}$ As later explanations put it, there would be no need for the Amicales Socialistes if they merely replicated the party sections from which they took their guidelines. ${ }^{25}$ At the start the party's agents de coordination called meetings reserved for party members; then, having established the guidelines, encouraged the party members themselves to form an Amicale Socialiste open to all members and sympathizers.

Until early 1937, the Socialist press kept a discreet silence about the party's new "front movement". Mentions of the Amicales Socialistes were limited to the items already cited and the announcements of meetings on the back page of Le Populaire. On January 11, 1937, Emile Farinet, secretary of the Seine federation of the SFIO, formally announced the existence of the new organization. In doing so, he outlined its structure and justified the party's decision to create it. Describing the Amicales Socialistes as a means of renewing the party's contacts with the working class, as a new conduit for recruitment to the SFIO, and as "an organism of working-class education that all syndicalist militants will be happy to see created" because of the need to educate the massive influx of recruits to the CGT, he warned against letting the new organization become an arena for factional competition ("in that case, [the Amicales Socialistes] would be real war machines against the party") and against letting it become too independent. To prevent the Amicales Socialistes from falling prey to the factions or to the machinations of outsiders, the new organization was to be kept under very tight party rein. Each section would be created by full members of the SFIO who would then attract sympathizers; all officers would come from among party members. The sections in an industry would form a "union" within each department, and this union in turn would be placed under the control of the SFIO federation in that depart-

23 Ibid., 18 September.

24 E.g., "Travailleurs socialistes, prenez note", ibid., 25 October, which included the following appeals: "Camarades coopérateurs. Sympathisants travaillant à l'entrepôt rue E. Doley sont priés de se réunir demain à 18 heures [...] pour fonder une amicale socialiste." And: "Ets. Bernard Roux, 13e. Réunion des membres du Parti et des sympathisants à 18 heures."

25 Emile Farinet, "Les Amicales Socialistes d'Entreprise", ibid., 11 January 1937 (Tribune du Parti section). 
ment. Dues were to be kept minimal and the sections and unions were to publish regular bulletins which focussed on "workplace incidents which would be denounced and analyzed". ${ }^{26}$

Shortly after the appearance of Farinet's article the CAP took the matter of party control one step further. It created a seven-member committee, known as the Comité National Consultatif des Amicales Socialistes, to oversee the movement at the national level. All of the members of this body were to be appointed by the CAP, and at least four of the seven would have to come from the thirty-three-member CAP itself. Later, when the movement's growth had produced a large complex body of Amicales Socialistes, this committee served as the "secretariat" for a larger body which also included the heads of the major Unions des Amicales Socialistes that came into existence. ${ }^{27}$ Desphelippon was named to head the national committee, a job he held from January 1937 until June 1940. One reason for the creation of this committee was the leaders' hope of encouraging the spread of the movement throughout the whole country. Another was to remove the movement from the exclusive control of the Seine federation, where the Pivertists and Zyromskists were growing in strength as frustration with the Popular Front mounted. Desphelippon's appointment was due not only to his role in founding the movement, but also to his positions on some of the touchy issues at the time of his appointment. As a syndicalist, he could be counted on not to let the Amicales Socialistes intrude on specifically syndicalist territory, thus avoiding crises with the CGT. As a recent member of Zyromski's Bataille Socialiste faction, he could be counted on to oppose Pivertist efforts to turn the Amicales Socialistes into activist comités de masses. As a supporter of the government's policy of non-intervention in Spain - he broke with Zyromski over this matter ${ }^{28}$-, he could also be trusted to oppose any efforts by advocates of intervention to use the friendship circles as pressure groups on the government.

Thus, the Amicales Socialistes, which had begun within the Seine federation and under its control, were quickly appropriated by the national

26 Ibid.

27 The Amicales Socialistes' official statutes were approved by the CAP on 20 October 1937. Parti Socialiste, XXXVe Congrès National, Rapports, 1938, pp. 148-51. On the later expansion, see the report entitled "Amicales Socialistes" and dated November 1938 in the Archives de la Préfecture de Police de la Seine, B/A1692 AS (henceforth cited as APP, Dossier).

28 Desphelippon signed the new Bataille Socialiste manifesto published in January 1936, following the split with the Pivertists, but he refused to follow Zyromski in advocating all-out support for the Republicans in Spain. See Zyromski's statement and the editorial "Au revoir!", in: La Bataille Socialiste, No 97 (November 1936). 
leadership and brought under its control. To be sure, the Seine federation continued to have its own director for the Amicales Socialistes, Claude Just, but he now had to operate in the context of directions set at the higher level. The Pivertists were to complain with some justice that the national leadership of the Amicales Socialistes tried to turn them into "Amicales Gouvernementales", but in the early formative stages neither Gauche Révolutionnaire nor Bataille Socialiste appears to have tried to make them anything else. Both groups of left-wingers were still focussing their attention on their own special interests - the Pivertists on the formation of comités populaires with Trotskyites and anarchists, the Zyromskists on unity with the Communists and the campaign for intervention in Spain. ${ }^{29}$ In consequence, the people who built the new organization and who dominated it were those Socialists who preferred more "internal" party efforts to the more "external" ones preferred by the left-wingers. The leadership of the Amicales Socialistes was to be dominated, in the main, by people more closely identified with Faure and Blum than with the left wing, and ultimately more with Paul Faure's faction than with that of Léon Blum. ${ }^{30}$

\section{Spread and Appeals}

Socialists and other observers were surprised by the great popularity that the Amicales Socialistes almost immediately revealed. Hardly had the idea been launched than hundreds of little groups appeared all over the Paris region. Clearly there was a large pro-Socialist clientele awaiting some word from on high and some appropriate vehicle for registering its support for the increasingly embattled Blum government. The spread of the Amicales Socialistes may also have been spurred by the law on collective agreements, passed on June 24, 1936, which stipulated that, in enterprises employing more than ten persons, the employees had the right to elect délégués d'atelier to oversee the collective agreement. The result, through the fall of 1936, was the election of thousands of such delegates. Although there is no evidence to link the election campaigns for those committees with the formation of the Amicales Socialistes, it seems reasonable to suggest that the competition for the positions helped to congeal the pro-Socialist ele-

29 As we shall see, the Pivertist group eventually attempted to take over the movement in the Paris region; however, Zyromski's followers never appear to have contested the limited role of the Amicales Socialistes. See, for example, the article by Louis Nermond, "Le Problème des Amicales Socialistes", in: La Bataille Socialiste, No 109 (May 1938).

30 Jean Leclercq, ibid., No 116 (April 1939). 
ments who did not want to support either the Communist or traditional syndicalist candidates. ${ }^{31}$

The earliest evidence of the organization's growth is impressionistic rather than statistical. A police report of January 13, 1937, on the reaction of the PCF's leaders describes their astonishment at the rapid spread of the movement.According to the information presented to a central-committee meeting, sections of the organization already existed in "most of the factories, businesses, workplaces and public and private administrations of the Paris region and that groups of this kind exist even in services where the formation of Communist cells has always failed. This is notably the case in the central administration of the Seine Prefecture." 32 The first statistic was volunteered by J.-B. Séverac, the assistant general secretary of the SFIO in April 1937, when he set the total in the Seine at "around eighty thousand workers". ${ }^{33}$ In November 1938, a police estimate set the total in the Paris region at "around 100,000, of whom the greater part are sympathizers". 34 In the Almanach Populaire for 1939 Desphelippon claimed that the national membership total was close to 200,000 , although he admitted that this figure was only an estimate. ${ }^{35}$ That it was perhaps inflated is suggested by a report of the Bureau of the Amicales Socialistes indicating that at the end of February 1939 only 30,000 cards had been sold, apparently a significant decline from earlier years. ${ }^{36}$ All of the sources indicate that the Amicales Socialistes were chiefly a phenomenon of the Paris region. On balance, it seems reasonable to conclude that the organization reached a total of around 100,000 members in the Paris region by the spring of 1937 and probably remained around that figure, with some upward and downward oscillations, until the end of 1938.

During these same years the total party membership in the Paris region (the Seine, Seine-et-Oise and Seine-et-Marne federations) stood at 29,507

31 Maurice Chambelland discussed the role of the "délégués d'atelier" at length in La Révolution Prolétarienne, No 235 (25 November 1936), pp. 377-83; he was particularly interested in the question of the relations between these delegates and the syndicalist movement, but one can see from his discussion the kinds of opportunities that the elections offered the political parties.

32 “A.S. de l'attitude du Parti Communiste à l'égard des Amicales Socialistes", 13 January 1937, APP, Dossier. A.S. means "Analyse Synthétique", a label used to identify analytic as distinct from field reports.

33 J.-B. Séverac, "Ce que sont nos Amicales Socialistes", in: Le Populaire, 5 April 1937.

34 "Amicales Socialistes", November 1938.

${ }^{35}$ Francis Desphelippon, "Les Amicales Socialistes", in: Almanach Populaire, 1939 (Paris, 1939), pp. 169-71.

${ }^{36}$ R. Boutin, reporting for the Bureau of the Amicales Socialistes, in: Le Populaire, 5 March 1939. 
in December 1936, 36,215 in December 1937, and 37,125 in December 1938. These figures, when compared with those for the Amicales Socialistes, suggest that in the Paris region in 1937-38 the latter's membership outnumbered the party's by a ratio of about 3 to 1 . If one assumes the rough validity of the 100,000 total and that three of four party members in the Paris region belonged to the Amicales Socialistes, one could set the likely number of militants in the organization in the Paris region at 25-30,000 and the number of sympathizers at $65-70,000$. These figures also suggest that the front movement did not serve as the kind of conduit to full party membership that its founders hoped it would be. Most of the sympathizers must have remained only sympathizers.

One reason it is hard to trace the actual membership of the Amicales Socialistes is that one of their purposes as a front movement was to create an impression of depth and breadth that specific figures might have belied. What was most significant about the movement, in any event, was that it provided platforms for Socialist leaders to address workers directly. Its chief function was to organize meetings in factories, shops and offices. The archives of the Prefecture of the Seine contain a file on many of the meetings convoked by the Amicales Socialistes, beginning in January $1937 .{ }^{37}$ The reports indicate the movement's broad reach and its popularity. The meetings ranged from little ones sponsored by single sections to large ones organized by the unions for entire industries. Apart from a few social occasions, the pattern of the meetings was constant: one or more speakers, usually chosen from the party's parliamentary group, its bureaucracy, or factional leaders, followed by a question-and-answer period. Efforts to determine the size of the audiences by industrial sector or by occupation are baffled by incomplete crowd estimates. However, on the basis of the frequency of meetings and the audience figures that are recorded, one can draw two tentative conclusions.

First, the rhythm of the Amicales Socialistes' growth and decline followed that of the membership itself: a marked rise to about May 1937; a slump over the summer; a modest revival in October and November; a resurgence from January to about April 1938; then two bursts of activity in response to the Daladier government's suspension of labour reforms in industries related to national defense in August and again in November 1938; followed by a slow decline through to the spring of 1940 . Second, the movement appears to have had three separate social bases: the industrial working class, the civil service, and employés in private industry. If the large "unions" of Amicales Socialistes in the industrial sectors held the largest

37 See note 27 . 
rallies - 2,000 at one meeting in the Renault works in 1937, 1,200 a few days later at a meeting of metallurgical workers -, the Amicales Socialistes among civil servants and employés in private firms held more frequent meetings and drew crowds ranging from 100 to 1,000 . The appeal of the Amicales Socialistes in the industrial sector appears to have been especially strong in the metallurgical, aviation, and construction trades. Perhaps next in appeal were the civil-service branches, especially in Finance and the PTT. But one is also struck by the large-scale and consistent support the Amicales Socialistes had in the white-collar sector - from clerks in banks, commercial and insurance companies, and from the staffs of department stores. ${ }^{38}$

The delimitations of the movement are suggested by the list of unions that were formed, although one can tell nothing from the list about the size of each of the unions. According to a police report, there were nineteen unions active in November 1938. These were known as the Union des Amicales Socialistes de l'A limentation; de l'Assurance Publique; des Assurances Sociales; de l'A viation; de Banque, de Bourse, et des Assurances; des Cheminots; de l'Industrie Cinématographique; des Communaux; des Ouvriers Coiffeurs; des Employés; de l'Industrie Hôtelière; du Livre; de la Métallurgie; du Métropolitain; des Porteurs de Gare; des P.T.T.; des Services Publics; des Transports; des Travailleurs du Bâtiment. These were only the unions for entire occupations; they rested, in turn, on about 1,500 Amicales Socialistes sections. In addition to the unions, the report indicates that there were several "federations" of sections that had their own regional networks in the Paris area. These included the Amicales Socialistes for the unemployed, small businessmen, artisans and small industrialists, the liberal professions, and "old workers". There was also an Amicale des Anciens du Parti for those who had been members for at least twenty-five years. ${ }^{39}$ Whether these federations were more than paper operations is impossible to say. One can find few traces of their activities.

More about the depth of the Amicales Socialistes in various sectors of the workforce can perhaps be read into the list of publications produced by the

38 Efforts to quantify the attendance at meetings are baffled by intermittent or impressionistic reporting of crowd estimates by police officials. Among the larger crowds in early 1937 were these: Renault workers (2,000 people, report of 21 March), metallurgical workers (1,200, 27 March), clerks in banks and commercial enterprises (900, 23 May 1937), white-collar workers in the insurance industry (500, 18 February), and civil servacts in the Ministry of Finance (200, 17 April). There were also "large" meetings of railroad workers (25 January), PTT workers (11 March) and a general assembly of members of the Amicales Socialistes in the Paris region (over 2,000, $25 \mathrm{March}$ ). Detailed reports can be found in APP, Dossier.

39 "Amicales Socialistes", November 1938. 
various unions. These were the titles contained in the November 1938 police report, with the publisher indicated in parentheses:

1) Vouloir (Amicales de la Métallurgie)

2) Le Socialiste des Transports (Amicale des Transports en commun, T.C.R.P.-Métropolitain)

3) A Toute Vitesse (Amicales des chemins de fer: grands réseaux, réseaux secondaires, wagons-lits, porteurs de gare)

4) Agir (Amicales d'employés de banque, de bourse et de commerce)

5) L'Envol (Amicales de l'Aviation)

6) L'Appel Socialiste (Amicales des P.T.T.)

7) Services Publics (Amicales des employés communaux et départementaux, services concédés)

8) L'A.P. (Amicales des services de santé et de l'Assistance Publique)

9) Le Livre Socialiste (Amicales du papier-carton, de la brochure, photogravare et clicherie)

10) L'Accélérateur (Amicales des ouvriers des Usines Citroën)

11) La Vague (Amicales des Ouvriers des Usines Renault)

12) Le Bâtiment Socialiste (Amicales des Travailleurs du Bâtiment)

On the assumption that a reasonably solid constituency would be needed to justify these publications, we can conclude that the unions of Amicales Socialistes listed here provided the chief strength of the movement. Again, one can see the chief pillars in heavy industry, the civil service, and the private white-collar sector.

One cannot go much beyond such general impressions of the social base of the Amicales Socialistes without far more study of political life in the shops, factories and offices of the period than has been undertaken so far. The other evidence that exists is far too fragmentary for generalization. In October 1937, Desphelippon remarked that the Amicales Socialistes in the aviation and metallurgical fields had been growing steadily - "they are attracting a considerable number of Socialist sympathizers" -, while he complained "that in Public Assistance the Amicales Socialistes bring only militants together" and deplored "the small numbers of their adherents in commerce and the food industry". ${ }^{40}$ In December, Gitton told the central committee of the Communist Party that the Amicales Socialistes were a particular threat in the CGT's "Fédérations des Métaux, du Bâtiment, et des Hôtels, Cafés, Restaurants et Bouillons", but his remarks probably indicated the areas where the Communists felt vulnerable, not necessarily those of great Socialist strength. ${ }^{41}$

40 “A.S. des Amicales Socialistes", 3 October 1937, APP, Dossier.

41 Report on PCF attitudes, 2 December 1937, APP, Dossier. 
What did the Socialists tell their sympathizers, once they got them to a rally or meeting? Were Socialist messages consonant with party policy? Did the Socialists tell the audiences what the audiences wanted to hear? To what extent did speakers seize the occasions for factional advantage? The questions must be asked, even if it is difficult to answer them.

Of course the messages varied with audiences and over time, as the focus of attention shifted. It was only natural, for example, that speakers addressing employés in the insurance industry should explain Socialist intentions for that industry, or those speaking to commerçants would explain the party's position on small business, or those addressing civil servants or industrial workers would speak to their specific concerns. It was only natural, too, that the party's line would change with the defeat of the Blum government and the slow disintegration of the Popular Front. Moreover, various speakers had their own pet subjects to which they always returned. The fiery Paul Faure rarely failed to expound with passion the party's opposition to war; Pivert always called on the workers "to support" the Popular Front by unspecified direct action; Desphelippon nearly always made the point that the Amicales Socialistes were in no way intended to interfere in syndicalist matters.

Still, some tendencies are clear. If there were differences in the themes touched on by speakers addressing different constituencies, they came down to this. Speaking to industrial workers, Socialists tended from late 1936 to early 1938 to call on the workers to have confidence in the intelligence, good will and resolution of Socialist leaders; from August 1938 to September 1939 to focus on protests against the loss of the forty-hour week; from late 1937 to May 1940 to dramatize the need to rally against the Communists in the union movement; and throughout the whole period to hammer on the party's dedication to peace. Speaking to fonctionnaires, Socialist speakers tended in the early period to focus on specific corporate concerns, especially the need for the fonctionnaires to develop their syndicalist strength, in the later period, to call for support for the party. Speaking to employés, Socialist speakers tended to focus on their need to join the party and the CGT, to speak in the future tense about the Socialist blueprint for society that would eliminate the "chaos" of capitalism, and to emphasize the party's democratic convictions. These different chords were not at variance with the party's formal policies and well within the boundaries of customary Socialist propaganda. Moreover, they made obvious political sense. The party's leadership was clearly fearful of working-class discontent and of the Communists' ability to capitalize on it; the fonctionnaires had long since come to see the party as their agent in Parliament; and the Socialists were fearful of the fascisant potential of the 
employés and commerçants, and eager to encourage their commitment to democracy.

As we shall see below, the Pivertists pursued their own themes, once they took over the Seine federation in January 1938. But their reign was to be short and their influence on the Amicales Socialistes not particularly important in the long run.

\section{The Amicales Socialistes and the Communists}

From start to finish the Amicales Socialistes were dominated by the SFIO's competition with the Communists. One might even say that they were a Socialist adaptation of a Communist device turned against the Communists themselves. Until the end of 1937, the aim of combatting the Communists was muted in public meetings; the party's speakers generally took the high road and called on the workers to join the party in order to support the Blum government or the Popular Front. However, the antiCommunist purpose of the Amicales Socialistes was no secret. Its mission in this respect had been signalled as early as November 1936 by Jean Lebas, then Minister of Labour, in a speech to the Socialist Party's national council. Although his language was oblique, its meaning was perfectly clear to his listeners:

Si nous laissions faire, indifférents, la tâche souterraine dont nous constatons certains effets, ce n'est pas seulement le mouvement syndical, mais aussi le Parti socialiste, parti ouvrier, ne l'oublions pas, qui serait sérieusement menacé. Avertis, vous prendrez vos dispositions. Je ne vous demande pas le vote d'une résolution. La parole suffit. Et quand on a compris, on fait son devoir. ${ }^{42}$

This call to arms was clearly intended to encourage the spread of the Amicales Socialistes as a means of combatting the Communist influence so much so that the Seine Prefecture's various "analytic" reports (incorrectly) described that as their starting point.

That the Amicales Socialistes were above all an anti-Communist manoeuver was taken for granted by the Communists themselves. A report dating from January 1937 in police files records the central committee's concern and their intention to try to undercut the Amicales Socialistes.

Les dirigeants communistes se rendent parfaitement compte que les "Amicales Socialistes" ont pour but essentiellement de contre-balancer l'influence des cellules communistes; ils savent aussi que si elles continuent

42 Le Populaire, 9 November 1936. Although the CGT's journal, Le Peuple, gave generous coverage to the council, it made no mention of Lebas's speech. 
leur progression au rythme de ces derniers mois, elles seront bientôt en mesure de lutter efficacement contre la propagande des cellules. Aussi viennent-ils de renouveler confidentiellement aux rayons et cellules leurs instructions et de leur prescrire de s'attacher, pour tous les moyens, à combattre la propagande et l'activité des “Amicales Socialistes". Il s'agit d'entraver leur développement dans toute la mesure du possible et d'agir en sorte que les éléments susceptibles de donner leur adhésion aux "Amicales" soient, au contraire, attirés vers les cellules. ${ }^{43}$

It is impossible to say how effective the Communists' "travail de noyautage et de désagrégation des Amicales Socialistes" was. It was conducted "prudently and adroitly", as Gitton wanted. One searches in vain through the pages of La Vie Ouvrière for any mention of the Amicales Socialistes. That the effort bore some fruit is suggested by the Socialists' narrowing of the definition of the Amicales Socialistes' proper clientele in 1937. Séverac took a particularly narrow line in April.

L'adhésion à une Amicale Socialiste doit être considérée comme la promesse d'une adhésion régulière au Parti, et celle-ci s'effectuera dès le moment où le travailleur, pleinement conquis à nos idées, désirera concourir plus activement à leur propagation et à leur triomphe. ${ }^{\mathbf{4 4}}$

However, this definition was hard to enforce in practice and it was not included in the Règlement finally adopted by the CAP in October 1937. The Règlement limited membership to "Socialist sympathizers who do not belong to any political party".45

The more important question, however, was how successful the Amicales Socialistes were in combatting the Communists' influence within the CGT. The answer appears to be that they were not particularly successful. To be sure, by establishing a Socialist presence in the workplace they provided rallying points for some workers who might otherwise have been attracted to the PCF, faute de mieux. But they certainly did not provide more than one element in a broader holding action designed to limit Communist influence within the CGT. Desphelippon's personal preference was to try to destroy Communist influence by constant denunciation of the Communist Party, a strategy which was counter-productive. As Desphelippon eventually admitted, the Amicales Socialistes did not

43 “A.S. de l'attitude du Parti Communiste à l'égard des Amicales Socialistes", 13 January 1937.

44 Séverac, "Ce que sont nos Amicales Socialistes", loc. cit.

45 "En créant les Amicales socialistes, le Parti entend grouper sur le lieu du travail (ateliers, usines, magasins, etc.) et sur le plan professionnel (paysans, artisans, commerçants, intellectuels) les socialistes et les sympathisants socialistes n'appartenant à aucun autre parti politique." "Règlement des Amicales Socialistes", in: Parti Socialiste, XXXVe Congrès National, Rapports, 1938, p. 148. 
manage to attract many ex-Communists. One of the prime reasons was that Desphelippon and those around him had given the organization such an anti-Communist reputation that even disabused former Communists felt awkward about joining it. This was true even in 1939-40, when the Communist movement collapsed and anti-Communism reached new popular peaks in France. ${ }^{46}$

\section{The Amicales Socialistes and the CGT}

The emergence of the Amicales Socialistes had quickly attracted the attention of syndicalist leaders, both Communist and non-Communist. In general, a police report indicates, the decision to create the front movement was "rather badly received in certain milieux of the syndicalist movement", including those leaders who belonged to the SFIO itself. ${ }^{47}$ It is not difficult to imagine the mixed feelings of many non-Communist syndicalists at such a moment. Confronted by a growing Communist "colonization" of the CGT, or parts of the CGT, fearful that the newly created syndicat unique would founder on the shoals of political differences, and yet anxious to prevent a Communist take-over of the CGT, the "traditional" syndicalists were neither wholly for nor wholly against the Amicales Socialistes. If they welcomed the implied support in the struggle against Communist "colonization", they were also worried about the implications of both Communist and Socialist activities for the future of "non-political" syndicalism. The result was an appeal to all parties to respect syndicalist independence in the summer of 1937, an appeal which the Communist and Socialist parties quickly accepted by reaffirming their formal respect. ${ }^{48}$

Concern about the role of the Amicales Socialistes was not merely about their politicizing effect. Especially in the fonctionnaire unions, where the interests of Amicales Socialistes members tended to focus on professional

46 Remarks by Desphelippon in "Les Amicales Socialistes de la Métallurgie Aviation, Assemblée d'Information", 11 February 1940, APP, Dossier. At the same meeting Madeleine Finidoni, propaganda secretary for the Amicales Socialistes in 1939-40, said: "Eh bien, à choisir, je préfère être fusillée par des gens de droite que par des communistes. Entre eux et nous, c'est une question de force, de vie ou de mort." Such antiCommunist expressions were increasingly common in Amicales Socialistes meetings from the end of 1938 to early 1940.

47 Théron, a Socialist member of the executive committee of the Syndicat National des Agents des P.T.T., was among those who feared that the Amicales Socialistes might trench on syndicalist activities. "A.S. de l'attitude du Parti Communiste à l'égard des Amicales Socialistes”, 13 January 1937.

48 Léon Jouhaux, unity appeal of 22 July, reprinted in full in Syndicats, 29 July 1937; the SFIO's reply was the formal acceptance of the Règlement for the Amicales Socialistes on 22 October. 
concerns, particularly in 1936-37, the syndicalists were fearful of the economic rivalry of the Socialist organization. Postal- and railroad-union officials sympathetic to the Socialists moved quickly to bring the movement under their own control and worked out a specific arrangement with the Comité National Consultatif providing for the right to create liaison groups within their own unions and to a large extent under their own control rather than under the control of SFIO sections and federations. It would be interesting to know more about the motives for and details of these special arrangements, which later inspired doubts within the SFIO. ${ }^{49}$

Syndicalist fears prompted the Socialists to issue a constant stream of denials, clarifications and restatements relating to the Amicales Socialistes' role in the places of work. In early 1937 Séverac was given the task of making the key definition in the pages of Le Populaire.

Les Amicales socialistes ne sont pas des organismes de lutte professionnelle. Elles n'assument aucune des tâches du syndicat. Elles ne se créent pas et n'agissent pas sur le plan économique. Elles sont des groupements strictement politiques et, à ce titre, non seulement sont respectueuses de l'indépendance du mouvement syndical, mais encore travaillent, toujours, conformément aux principes d'action de notre Parti, au recrutement, au développement et au renforcement du mouvement syndical. [...]

On le voit, aucune confusion n'est possible: là, action revendicative professionnelle au sein de la C.G.T.; ici, action politique se rattachant à celle du Parti socialiste et relevant de ses directives. ${ }^{50}$

There was a related area of concern which the Socialists mentioned rarely but which crept into the Règlement, without doubt because of syndicalist fears: the elections for the délégations ouvrières. Forbidding "any incursion in the syndicalist realm", the Règlement specified that, among other things, "respect for the autonomy" of syndicalism meant that the Amicales Socialistes should "not weigh in any fashion, in any circumstance, on the decisions of the workers' delegations elected by all of the workers and employees of each enterprise".

The most serious challenge to Socialist-CGT relations posed by the Amicales Socialistes came from Gauche Révolutionnaire, which grew steadily throughout 1936 and 1937 . With Bataille Socialiste, it managed to

49 This concession was made in the Règlement as follows: "Le mouvement des Amicales est organisé sur la base fédérale, dérogation est faite par les cheminots et les postiers dont les Amicales, tout en restant sous le contrôle et la direction politique de leurs sections locales et de leurs fédérations [du Parti], pourront respectivement organiser entre elles une liaison nationale." A re-examination of "the special situation" given to the PTT and railroaders' unions was promised by Marceau Pivert, then federal secretary of the Seine federation, "Aux Amicales Socialistes", in: Juin 36, No 2 (5-20 March 1938).

50 Séverac, "Ce que sont nos Amicales Socialistes". 
defeat the Blum-Faure coalition at the extraordinary national-council meeting of 17 January 1938 (over the issue of further participation in cabinets with the Radicals), thus shaking but not quite dislodging the chiefs of the party's bureaucracy. On 23 January; Gauche Révolutionnaire won an even more spectacular victory in the Seine, taking 7,450 mandates to 4,087 for Bataille Socialiste and 3,688 for the Faurist faction. By this time the Pivertists had meditated long on their failure in 1936 to capitalize on what they came to see as a missed revolutionary opportunity. All had observed the lack of significant contact with the working class itself. Trotsky himself had written to his French followers calling for Soviets rather than Popular Front committees or reliance on bourgeois democracy; his letter was published on June 12, 1936, too late to make a difference, but the memory lingered on among the Pivertists. Pivert himself had concluded that small, well-organized minorities having close contacts with the working class, enjoying its confidence, with a clear purpose, could transform another "Juin 36" into a successful revolution: "rien ne peut résister à cette association, dans le mouvement, entre des éléments moteurs et des masses mobilisées et entraînées avec la rectitude d'une avalanche irrésistible."51 Apparently the Pivertists were able to create small groups of their own in some factories, notably in the 15th arrondissement, Pivert's own fief. Increasingly the burgeoning Amicales Socialistes came to have a new allure for them, especially as Gauche Révolutionnaire's rising strength in the Seine federation placed the formal leadership of the Seine federation's Amicales Socialistes in their hands in late 1937 and early 1938.

In November 1937 Daniel Guérin of Gauche Révolutionnaire became the director of the Amicales Socialistes in the Seine. With Lucien Vaillant and Maurice Jacquier of the same faction, he moved swiftly to transform the Amicales Socialistes from the defensive, circumscribed organization they were into aggressive combative ones, the potential catalysts for revolutionary activity. There is no source indicating how much support the Pivertists had within the Amicales Socialistes themselves, but it seems certain that they had some. After all, they commanded the support of nearly one-half of the party's members in the Paris region by that time. However, it also seems likely that their control of the apparatus of the Amicales Socialistes did not go very far. They had played little role in the organization during its emergence and by the end of 1937 found it dominated by opponents of their faction or by syndicalists who wanted to keep the Pivertist brand of politics out of the factories, offices and shops of the Paris region. They also had to reckon with the Comité National Con-

51 Marceau Pivert, Pour une politique de classe (Paris, 1937), p. 23. 
sultatif, which immediately moved its own headquarters into the Seine federation's offices, the better to keep the movement under control. The Pivertists raised a storm of protest, but to no avail before other events put the matter in the shade..$^{52}$

Gauche Révolutionnaire took control of the Seine federation at a time of increasing working-class restiveness. By late 1937 inflation had severely eroded the salary gains set by the collective agreements of June 1936. The collective agreements affecting metallurgical workers had been extended from June 1937 to 31 December and then to 28 February 1938, by which time the leaders of the metallurgical union reckoned that their wages had fallen 28 percent behind the rate of inflation. ${ }^{53}$ At the same time, many employers were anxious to undo the concessions made in 1936 and hoped to take advantage of the disintegration of the Popular Front alliance to re-establish their authority in the factories. ${ }^{54}$ Together, working-class discontent and employers' intransigence precipitated a wave of strikes in late 1937 and early 1938, notably in metallurgical, rubber and food processing industries and in the public service. The occupation of the Goodrich rubber factory by workers in Colombes on 23 December was particularly notable, for it sharpened factional differences within the SFIO and crystallized discontent with the party's continuing participation in a Radicalled cabinet. Marx Dormoy, the Socialist Minister of the Interior in the Chautemps government, took the responsibility for ordering the Gardes Mobiles to vacate the factory on 30 December. Although Dormoy ordered a retreat when a huge crowd of sympathizers gathered, the incident revealed the measure of working-class discontent, the readiness of at least some workers to return to "the methods of June 1936", and above all the pitfalls of continued Socialist participation in Popular Front governments. The affair undoubtedly contributed to the defeat of the Blum-Faure resolution to sustain that participation at a national-council meeting in mid January 1938.55

These, then, were propitious circumstances for the Gauche Révolutionnaire to propagate its views about the need for a more activist role by the 52 Guérin, Front populaire, op. cit., pp. 180-81; also id., "Où vont les Amicales Socialistes", in: Les Cahiers Rouges, December 1937, and "Sortons enfin de l'équivoque!", ibid., January 1938; and "A.S. des Amicales Socialistes", 21 December 1937, APP, Dossier.

${ }^{53}$ A. Vrigneaud, "L'Intransigeance patronale, cause essentielle du mécontentement", in: La Vie Ouvrière, No 974 (31 March 1938); somewhat different figures were ventured by Gratignol, "Pour le secrétariat de l'Union Syndicale des Métallurgistes de la Région Parisienne", cited in an article entitled "L'Intransigeance patronale, cause de l'élargissement des conflits", ibid., No 976 (14 April).

54 Patrick Fridenson, Histoire des Usines Renault, I (Paris, 1972), pp. 267-69.

55 Guérin, Front populaire, p. 182; Daniel Mayer in Le Populaire, 29-31 December 1937. 
Amicales Socialistes in the factories. But talking was one thing; getting the section leaders of the Amicales Socialistes, much less the sympathizers, to go along was another. The most notable instance where the Pivertists attempted to impose their own policies on the Amicales Socialistes came in march and April 1938, just as Blum was trying to establish a new government "in the image of the Popular Front of 1936". The Pivertists were determined to give this second Blum government the same kind of popular support - that is, visible support by the "masses" - that its predecessor had had, and in practice that meant trying to use the sections of the Amicales Socialistes as catalyzing agents for a "mass movement" ${ }^{56}$ However, the international situation had changed considerably since June 1936, and Blum's second government was less interested in social and economic reform than in national defence, a subject on which Blum stood at opposite poles from Pivert. Blum's effort to create a second government came about in the immediate wake of the Anschluss and of Chautemps's most curious abandonment of office on the very eve of that event. Blum appealed for national unity in the face of the international crisis, and called in representatives of defence-related industries and the leadership of the Fédération des Métaux to discuss the need for increased defence production. According to Vincent Auriol, who was present at the meeting, Blum secured agreement from both employers and union leaders to collaborate in order to enhance production in defence-related industries, including "supplementary hours" for workers. ${ }^{57}$ However, on 24 March sit-in strikes began in the Citroën works and spread within days, through the seven Citroën plants, to the Renault works and to the aviation industry. Once again the Socialists were in office and confronted by strikes whose illegal form they were obliged by their government responsibilities to denounce. As in 1936, the party's leaders attempted to settle the strike by negotiations carried out under their auspices. But this time the technique did not work. The representatives of the metallurgical union - almost all Communists agreed to terms that were a few days later repudiated by their followers.

56 In March, the Pivertist-dominated executive committee of the Seine federation attempted to reorganize the Amicales Socialistes to make them better equipped for action, insisted that all future Amicales publications appear in Juin 36, which would then be distributed in shops and factories, and made an effort to get all Amicales Socialistes' leaders to attend the federation's propaganda "school". Pivert, "Aux Amicales Socialistes", loc. cit. When the Pivertists formed their own party (the PSOP), they tried to rectify the SFIO's "errors" in its Groupes Révolutionnaires d'Entreprise, notably by obliging all party members to belong to its sections at their place of work. See "Le P.S.O.P. et les Groupes d'Entreprises (Résolution votée par la Conférence)", in: Juin 36, No 18 (22 July 1938).

57 Vincent Auriol in Le Midi Socialiste, 18 April 1938; see also Daniel Mayer in Le Populaire, 26-27 March. 
The owners then refused to negotiate so long as the strikers continued to occupy the factories. ${ }^{58}$

In this situation, the national and Seine leaderships of the Amicales Socialistes took diametrically opposed views. André Blumel, chef de cabinet of Blum and a member of the CAP's Comité National Consultatif, called in the heads of the Union des Amicales Socialistes de la Métallurgie and told them that, unless the strikes were over by 28 March, "Blum s'en va et vous aurez Pétain". ${ }^{99}$ Responding to this pressure, the executive committee of the Union then published a rather ambivalent resolution, which denied the "rumours" circulating in the Citroën factories that the Union was involved in fomenting or precipitating the strikes, and which affirmed "sa confiance à la fois dans l'action propre de la classe ouvrière et dans celle du gouvernement de Front populaire à direction socialiste, pour le maintien et l'élargissement des conquêtes de juin 1936". ${ }^{60}$ However, accompanying this resolution was a front-page editorial in Le Populaire by Bracke saying that, if the Amicales Socialistes had broken their own rules by interfering in syndicalist affairs, the party would see that it did not happen again. And Desphelippon, in a bitter denunciation of the Communist attempt to blame the Amicales Socialistes for prolonging the strikes, pointed out that the Communist-led Fédération des Métaux had not itself come out openly against the strikes. Moreover, he added, the Amicales Socialistes,

qui savent la légitimité des revendications ouvrières, qui comprennent l'impatience de leurs compagnons de travail, qui pensent qu'il n'est pas possible de tolérer du patronat qu'il persiste à ne pas vouloir s'incliner devant la loi commune, n'en sont que plus à leur aise pour demander aux socialistes et aux sympathisants socialistes d'abandonner un mouvement dont personne ne revendique la responsabilité, et de cesser une grève dont la prolongation ne peut que créer, pour le gouvernement de Front populaire à direction socialiste, des difficultés dont la réaction et le fascisme ne manqueraient pas de profiter. ${ }^{61}$

58 Guérin, Front populaire, pp. 183-84.

59 Quoted in Guérin, "Nous, Les Pestiférés", in: Juin 36, No 6 (1 May 1938).

60 "L'Ordre du jour de l'Union des Amicales Socialistes de la Métallurgie", in: Le Populaire, 28 March 1938; it was signed by Augustin Trésurier and Cuissot.

${ }^{61}$ Bracke, "Ce que disent nos Amicales Socialistes", and Desphelippon, "Une Réponse à l'Humanité et Ce Soir", ibid. See also the article entitled "Précisons" demonstrating the deliberate falsification by L'Humanité of a statement on the strike by the Syndicat des Métaux Parisiens; the falsification took the form of an additional paragraph which implied strongly that the Amicales Socialistes were working to prolong the strike. The syndicalist Vie Ouvrière, by contrast with L'Humanité and Ce Soir, never mentioned the Amicales Socialistes and accused the Trotskyites of being a "fifth column" for the employers. Vigny, "Une manoeuvre de grande envergure", in: La Vie Ouvrière, No 975 (7 April 1938). 
That same day Guérin prepared and circulated a statement repudiating this appeal to end the strike, expressing the Amicales Socialistes' solidarity with the workers in their "grande lutte" with its "valeur demonstrative", and in effect urging the strikers to continue: "Salut aux métallos en grève. En défendant leur pain ils protègent nos libertés et la paix."'62

The struggle between the Pivertists and the national leadership of the Amicales Socialistes was only part of the struggle between the Pivertists and the party's hierarchy, to which Zyromski and his followers rallied after their initial leftist consolidation in January. In that struggle the Pivertists went further than ever in accusing the leadership, notably Blum, of having in effect betrayed the working class by subjecting working-class interests to those of "national unity", and the party's bureaucracy responded by extreme measures of its own. On April 12 the party's Commission Nationale des Conflits, seizing on technicalities that did not involve the Amicales Socialistes, suspended Pivert, Guérin, Jacquier and others from their functions; and on April 14 the party's secretariat dissolved the Seine federation itself, reconstituting it only for those who would pledge to abide by the party's rules. These sanctions were approved by the Royan congress in June, following which the hard-core Pivertists created their own party, the Parti Socialiste Ouvrier et Paysan. ${ }^{63}$

There are no reliable figures showing what proportion of the Amicales Socialistes broke away to join the new Pivertist party. It appears that the schism only marginally influenced the organization. Desphelippon claimed that 98 percent of its members remained with the SFIO. ${ }^{64}$ Even the Pivertists did not claim to have attracted much support from within the Amicales Socialistes; their chief clientele, after the schism, came from among 10-15,000 former SFIO members (a year later, the figures were only half that). On balance, then, it appears reasonable to suggest that the Pivertists never commanded more than the Seine federation's central offices of the Amicales Socialistes, and attracted only a relatively small band of followers among the members and sympathizers of the Amicales Socialistes.

Did the Amicales Socialistes - Pivertist elements or otherwise - play any part in launching or prolonging the metallurgical strikes of March-April 1938? The answer cannot be categorical. Obviously the branches under Desphelippon's leadership were not an active agent in producing or sus-

62 Guérin, Front populaire, p. 183.

${ }^{63}$ For some reason Joubert ignores the tussle within and over the Amicales Socialistes in his monograph, Révolutionnaires de la S.F.I.O., pp. 137-52, where he describes the growing rupture between the Pivertists and the mainstream of the SFIO.

64 Le Populaire, 15 May 1938. 
taining the strikes, but they were not by and large as clear as Desphelippon himself was in opposing the continuation of the strikes. It seems clear that the Pivertists were insufficiently numerous or well-placed to play any decisive role. What can be said is that the Pivertists certainly contributed to an environment in which this "return to the methods of June 1936" was seen as desirable by some workers. For months they had been calling for a return to a Socialist-led Popular Front government and asserting that when it came it would need the support of a Front Populaire de Combat among the masses along the lines of that in June 1936 - but this time sustained into the indefinite future. When the second Blum government was actually formed in March 1938, that argument plainly gained in relevance. It is impossible to document or trace its influence among the men who actually went on strike, and one did not need to be a Pivertist at the time to reach similar conclusions. ${ }^{65}$

This rather remarkable affair did not leave any noticeable trace on formal relations between the SFIO and the CGT. One reason was undoubtedly that the ouster of the Pivertists soon returned the Amicales Socialistes to a more tranquil function. Another was the fact that in the next few months threats to the forty-hour week began to multiply, uniting Socialists, Communists and syndicalists in a chorus of opposition to the Daladier government's policies. Yet another reason was a growing partnership between the Paul Faurist element that thenceforth dominated the Amicales Socialistes at both the national and Parisian levels and Belin's Syndicats group within the CGT. What brought them together was a desire for peace at any price and anti-Communism. Although Belin's group was precisely that which had been most vocal earlier in opposing political interference in the CGT - and still issued the by now ritual criticisms of

65 See the detailed articles by Auriol in Le Midi Socialiste, 17-22 April 1938, which explore the role of the Communists and others. As Auriol makes clear, the Communists were pulled in conflicting directions and consequently played a double game. On the one side, as supporters of national defence they wanted to end the strikes and to increase productivity; on the other, as syndicalists, they wanted to keep in touch with the most radical working-class sentiment, to get the best possible settlement for the workers, and to meet the competition of the Trotskyites and other radicals for their clientele in the factories. In private negotiations, they were firm but not provocative; at the level of shop-floor activity, their representatives were leading the chorus of demands for catch-up wages and better working conditions. Although Guérin has persuaded himself in retrospect that the strikes were "spontaneous" (Front populaire, p. 184), he said at the time that "Presque partout l'initiative de la grève a été prise par les cadres syndicaux de base", Juin 36, No 4 (8-22 April 1938). A. Habaru, "Les Grèves, leurs origines et leurs leçons", reprinted in La Voix Socialiste (Charente-Inférieure), No 205 (23 April 1938), insisted that it was to divert attention from their own ambiguous role that the Communists made charges against the Trotskyites and Pivertists; the latter groups had only "une influence insignifiante dans les grandes usines". 
both Amicales Socialistes sections and Communist factory cells at the 1938 Nantes congress ${ }^{66}$, foreign and defence policy by this time had become so overriding a concern that older loyalties were breaking down on all sides and new ones were taking shape. Similar views and values were increasingly bringing Faure's faction, known then as Pays Socialiste after its journal, and the Syndicats group together. While it is certain that the Amicales Socialistes served as a natural bridge between them from mid 1938 to 1940 , it is impossible to say how much concerted collaboration there was between the leaders of the Amicales Socialistes and Belin's group and what role, if any, the "Munichois" line of Faure, Desphelippon and others might have had in the apparently sharp decline in Amicales Socialistes membership in that period. ${ }^{67}$

\section{Conclusion}

The foregoing account of the Amicales Socialistes hardly exhausts the subject. Many questions cannot be answered about the movement until studies are made at the level of specific industries and factories. However, certain things are clear. The Amicales Socialistes were not created by the wing of the party eager to evangelize the masses, eager to permeate the large inchoate mass movement represented by the Popular Front and to turn it subtly or abruptly in directions desired by the Socialists. On the contrary, the men who created the Amicales Socialistes aimed at only modest and defensive goals - chiefly to stabilize the volatile working class, to combat the rising influence of the Communists in the labour movement, and to further party recruitment. The leadership's conception of the front organization required a strict subordination to the party hierarchy. That subordination had the advantage that the Amicales Socialistes could not

66 E.g., Georges Dumoulin and André Delmas in Confédération Générale du Travail, Congrès Confédéral de Nantes, Rapports Moral et Financier, Compte rendu sténographique des débats, 1938, pp. 184-85, 225-27.

67 I did not detect any indication in the police files of a formal or secret agreement between the Syndicats and Amicales Socialistes groups. None was needed: both were tending in the same "pacifist" and anti-Communist directions and towards a later "collaborationist" posture. The "pacifist" and "revolutionary defeatist" elements in both the CGT and SFIO collaborated in the creation of the Centre Syndical d'Action Contre la Guerre (CSACG) in the spring of 1938, just prior to the SFIO's Royan congress. (See the announcement of a "national information assembly" to fight the growing "war psychosis" in Juin 36, No 10 (27 May 1938), p. 6.) By the end of 1938 this Centre was openly supporting the Faurist forces within the SFIO in Syndicats, 28 December 1938 and 11 January 1939. Henry Ehrmann, French Labor, From Popular Front to Liberation (New York, 1947), p. 304, notes 2 and 10, speculates about contacts between various groups of "pacifists" and "defeatists" and specifically mentions an accord between Paul Faure and Pierre Laval, but provides no evidence for these remarks. 
easily be turned against the party's leaders. It had the considerable disadvantage that the Amicales Socialistes' role as an auxiliary organization was severely limited. Where they might have been used far more effectively than they were to distinguish between SFIO policy and the compromises of the Popular Front, thus enabling the Amicales Socialistes to canalize some of the discontent with the Popular Front, they were used instead to defend the Popular Front strategy at nearly every turn. In consequence, the organization was pretty much confined to party members and very strong sympathizers. One finds it hard to imagine that the Amicales Socialistes were very effective in extending the party's base much among those who had turned away from the party or were unsympathetic.

The Amicales Socialistes revealed the spreading influence of the SFIO among civil servants and employés as well as its ability to attract support from some sectors of the industrial working class. In this respect one needs to revise somewhat the judgment of Antoine Prost, who, referring to the growth of the Communists' influence in the period, commented that the SFIO also grew, but "especially in petty-bourgeois milieux". He added: "Joining the Socialist Party can have, for the wage-earners in [tertiary] services, more conservative in a climate of greater security, an import as revolutionary as joining the Communist Party can have for wage-earners in metallurgy or chemical products." 68 Although perceptive, Prost's remark may exaggerate the Socialist Party's loss of working-class support in the Paris region and fails to distinguish adequately between the party's appeal to fonctionnaires and to employés in private industry. One might also add this small change: that, if to belong to the SFIO was a badge of radicalism for the fonctionnaire, belonging to the Amicales Socialistes was a sufficient badge of radicalism for many of the employés and small businessmen who rallied to the Socialist cause in the Popular Front era.

In the end, the Amicales Socialistes were an interesting political experiment undertaken by a party characterized by caution and timidity. Were they a success or a failure? The answer depends upon one's perspective. From the vantage point of Socialist leaders in 1936-37, they were a success. They appeared to rally the support of a good many people who would not make the greater commitment of joining the SFIO itself. They established a Socialist "presence" in the workplace, a presence that the party was to continue, through revived Amicales Socialistes, after the Second World War. In retrospect, however, the Amicales Socialistes of the 1930's must be judged a failure. If they played any role in stemming the growth of Communist influence in the CGT, it did not stop the Communists from

68 Prost, La C.G.T., p. 156. 
eventually dominating the movement. If their aim was to enhance party recruitment, the fact remains that nearly three-quarters of their members did not join the SFIO. As for their stated goal - that of disseminating party policy among the masses -, it was frustrated, first by the need to justify Popular Front governments, and then by the growing contradictions in the SFIO's own policies, specifically on national defence. In addition, the Amicales Socialistes were hedged in on all sides. They were unable to focus on the corporative demands of workers because of the party's fear of alienating the CGT; they were unable to address general concerns - for example, "defence of democratic liberties", anti-fascism - without constant reference to Socialist policy, thus frightening off some who might have gone at least that far; and they were unable, because of their close tie to the party apparatus, to harness and divert discontent with Popular Front governments into support for the SFIO's own policies.

To some extent the Socialists' nervousness about a looser form of organization derived from their own traditionalism, from their inability to accept rapidly the need for major changes in their relations to trade unions or to mass movements. It also derived from the knowledge that the party was not tightly enough organized in shops and factories to enable the party to be adventurous. As Desphelippon looked back, in February 1940, he regretted that the Amicales Socialistes had not been "sufficiently well organized". ${ }^{69}$ The problem, however, was less organizational than it was one of purpose. His response to his own feeling of failure was perhaps symptomatic. Such caution, such "fidelity to the traditions", often amounted to immobilism and ritualism. Given a less defensive posture and more tactical opportunism, the Amicales Socialistes might have been more effective in extending Socialist influence, in permitting the SFIO to play a larger role in choreographing public events, and in competing with the Communists. However, even as one formulates such criticisms, one can hear in one's mind the objections of the Socialists themselves. They were men who wanted the support of others out of conscious conviction, not because of cynical manipulation. They generally said what they believed and invited others to support them on that basis. The idea of "front movements" focussing on generalized slogans or specific complaints did not appeal to them.

Thus, the Amicales Socialistes remained relatively modest operations during the late 1930 's. They were partly limited by "objective" circumstances. Having left the organization of workers at the place of work to

69 "Les Amicales de la Métallurgie Aviation, Assemblée d'Information", 11 February 1940. 
the syndicalists and Communists, they had a considerable deficit to make up and encountered the suspicions of trade unionists who were otherwise their allies. Their petty-bourgeois clientele was heterogeneous and timid, hard to mobilize for more than occasional political rallies. Their civil-service supporters, perhaps more hardy, nonetheless tended to flow to the Amicales Socialistes when the SFIO was in office and to fall away as it lost power. But the greatest weakness of the Amicales Socialistes was probably "subjective" - the cautious, defensive conception that characterized the party's conception of what they could or should be. ${ }^{70}$

${ }^{70}$ The article by Jean-Pierre Rioux, "Les socialistes dans l'entreprise au temps du Front populaire: quelques remarques sur les Amicales socialistes (1936-1939)", in: Le Mouvement Social, No 106 (1979), pp. 3-24, appeared after this piece was committed to the press. 